\title{
STRUCTURAL METAPHORS IN THE ENGLISH AND HUNGARIAN VERSIONS OF GEORGE ELIOT'S MIDDLEMARCH
}

\author{
GÁBOR BEZECZKY \\ Institute of Literary Studies, HAS, Budapest, \\ Hungary
}

\begin{abstract}
When we are trying to decide whether the translation of a particular novel is good or bad, we shall usually find that there are quite a few equally valid points of view and powerful arguments on both sides. It should also be noted that in order to reach a decision it seems necessary to by-pass temporarily the views according to which languages are incompatible and translation is either impossible or illusory. Putting aside the views on linguistic relativity does not simplify matters, it just makes the decision possible. The temporary suspension of such views is, to some extent, justified by the practice of those people who correlate texts in different languages and look upon them as saying the same thing. They may be wrong and the supposedly identical texts can turn out to be different, but it must be admitted that identity in cultural matters is always arbitrary. If people insist on translating as they obviously do, there should be some criteria within the theoretical framework of translatability to judge the relative merits and failures of what they produce.
\end{abstract}

One of the possible approaches to the translations of literary works of art is fairly simple. We can take the interpretations of the original as our guide, and try to find out whether the translation allows the same, or at least similar interpretations. J. Hillis Miller's essays on George Eliot's Middlemarch seem to be ideal for this purpose. ${ }^{1}$ His interpretation is linguistic in the sense that it is based on identifiable linguistic structures and he quotes the text of the novel more than seventy times. The goal of the investigation is to see whether and how the linguistic structures he relied on are present in the Hungarian version of the novel.

Miller says that some of the masterworks of Victorian fiction are engaged in the enterprise of totalisation. They "have many characters and employ multiple analogous plots. They cast a wide net and aim at inclusiveness, in part by a method of accumulation." 2 The methods of totalisation vary from novel to novel. The narrator of Eliot's novel employs "certain all-encompassing metaphors which are proposed as models for Middlemarch society. Such metaphors are put forward as a means of thinking of all the people in Middlemarch in their interrelations through time. Each metaphor is an interpretive net which the reader is invited to cast over 
the whole society, to use as a paradigm by means of which to think of the whole. I shall argue that there are three such totalizing metaphors, or rather families of metaphors." ${ }^{3}$ The first group of metaphors includes woven cloth flowing water. ${ }^{4}$ Visual and optical metaphors belong to the second group, while reading, signs and interpretation makes up the third group. Miller adds that "Each group of metaphors is related to the other, fulfilling them, but at the same time contradicting them, canceling them out, or undermining their validity."

The new context in which the metaphors Miller points out ought to emerge is somewhat different from the original. The general characteristics of the translation are easy to establish.

First of all, the Hungarian version must be considerably shorter than the original. Words, clauses and even whole sentences are missing. The examples are too numerous to list.

Shift the pegs a little, he said to himself, and Mr. Brooke might be in the Cabinet, while I was Under-Secretary. That is the common order of things: the little waves make the large ones and are of the same pattern. I am better here ... (p. 501.)
Nem is kell hozzá csoda - bizakodott -, és Mr. Brooke egy szép napon beül a bársonyszékbe, én meg az államtitkárja leszek. Megteszi ő is, ha nincs jobb. Könnyebben beletalálkozok ebbe az életbe, ... (II/42.)

Actually, this is one of Miller's examples. He says that the first group of metaphors relies on the assumptions that society "is open to the same kind of objective scientific investigation as may be applied to such a field, for example, to flowing water" and that "the structure or texture of small-scale pieces of the whole is the same as the structure or texture of the whole and so may be validly described with the same figures. ${ }^{\prime 6}$ However, both the structural metaphor of flowing water and the reference to the identity of the small-scale and large-scale pieces are missing from the Hungarian version. In addition, the function of the missing sentence is to connect the first and second group of metaphors, which include visual and optical metaphors. ${ }^{7}$ The metaphor of weak and strong lenses, for example, partly fulfills, partly undermines the metaphors, which assume that no change of perspective can yield different results. ${ }^{8}$ With the sentence missing, these aspects of the novel must remain unknown for the Hungarian reader.

Secondly, there are quite a few passages in the Hungarian version which do not even remotely resemble the English text.

Nothing could hinder it but her love of extremes, and her insistence on regulating life according to notions which might cause a wary man to hesi-
Más meg nem akadályozhatta, mint a szélsőségek iránti vonzalma, és ragaszkodása olyan életszabályokhoz, amelyek alkalmasak az óvatos kérö 
tate before he made her an offer, or elgondolkodtatására, vagy éppen even might lead her at last to refuse elrettentésére (I/11).

all offers (31).

"...lead her ... to refuse all offers" and "...éppen elrettentésére" are certainly different. The Hungarian sentence, as opposed to its English counterpart, makes no mention of the possibility that it is Dorothea who may refuse the offers. The Hungarian sentence says something else instead.

Let us take another example:

I at least have so much to do in unraveling certain human lots, and seeing how they were woven and interwoven, that all the light I can command must be concentrated on this particular web, and not dispersed over that tempting range of relevancies called the universe (170).
Nekem legalább az emberi sorsok gombolyítása körül annyi tennivalóm, bogaikat oldozván-kötvén, hogy a gubancra rámegy a napom, ezért érdeklődésemmel nem fordulhatok a világegyetemnek nevezett csábítóbb s tágabb terek felé ( I/173).

One of the important differences between the two texts is that the narrator of the first is only an observer while that of the second actively participates in the creation of the events that happen to the characters of the novel. The narrator of the Hungarian version not only creates the events, he makes mistakes, that is, unwanted knots, 'gubanc' as well. This is, again, one of Miller's examples presenting two of the structural metaphors, the woven cloth and seeing. ${ }^{9}$ Due to the fact that the narrator is turned into a participant, the second metaphor is altogether missing from the Hungarian version and the first is somewhat distorted. 'Web' is certainly not 'gubanc' or 'érdeklödés' and "all the light I can command" is rather different from "a gubancra rámegy a napom." In addition, the function and tone of the sentence is also different: the English counterpart of "a gubancra rámegy a napom" is an explanation, while the Hungarian text appears to be a complaint bordering on a slightly hysterical exclamation. Finally, the Hungarian text places the narrator in the wrong social context. A sentence like "a gubancra rámegy a napom" belongs to the register used by low-level secretaries or administrators. It is no wonder the word 'relevancies' is also missing.

In general, the Hungarian narrator uses a vocabulary from which the theoretical vocabulary and the learned words are either absent or in which they are exchanged for more concrete words and phrases: what is "inconsistency and formlessness" in the original becomes "handabandázás" in the Hungarian version.

Many Theresas have been born who found for themselves no epic life wherein there was a constant unfold-
Azóta is sok Teréz született. Magasztos életük nem bontakozhatott ki messze hangzó tettekben. Talán csak 
ing of far-resonant action; perhaps only a life of mistakes, the offspring of a certain spiritual grandeur illmatched with the meanness of opportunity; perhaps a tragic failure which found no sacred poet and sank unwept into oblivion. With dim lights and tangled circumstance they tried to shape their thought and deed in noble agreement; but after all, to common eyes their struggles seemed mere inconsistency and formlessness (25). csetléssel-botlással teljes sors jutott nekik, a lelki nagyság és a kisszerü lehetőség tökéletlen illeszkedése. Talán tragikus bukás lett az osztályrészük, úgy merültek el a könnytelen feledésben, hogy megéneklőjük sem akadt. Szűkagyúan, a körülmények gubancában próbálták eszményüket tetteikkel egybehangolni, a közvélemény előtt végül mégis minden küzdelmük handabandázásnak látszott (I/5-6).

The Hungarian narrator speaks some sort of purified language in which there are no words of Latin, Greek or German origin. As a corollary, 'metaphor' is replaced by 'hasonlat.' Is the Hungarian reader not supposed to know words like 'következetlenség,' 'formátlanság' or 'metafora'?

for we all of us, grave or light, get our thoughts entangled in metaphors, and act fatally on the strength of them. (111).
Mert mi mindnyájan, szántsunk bár mélyen vagy a felületeken, hasonlatokba bonyolódunk, s ezekhez képest járunk el, vesztünkre (I/104).

When we are describing the relationship and movement between the two texts, outright mistakes, like the correlation of "the very eye of the research" and "a kutatás szeme" in the following example, are somewhat less interesting than the characteristic transformation of the original.

But these kinds of inspiration Lydgate regarded as rather vulgar and vinous compared with the imagination that reveals subtle actions inaccessible by any sort of lens, but tracked in that outer darkness through long pathways of necessary sequence by the inward light which is the last refinement of Energy, capable of bathing even the ethereal atoms in its ideally illuminated space. He for his part had tossed away all cheap inventions where ignorance finds itself able and at ease: he was enamoured of that arduous invention which is the very eye of research, provisionally framing its object and correcting it to more and more
Lydgate részeg nagyzolásnak minősítette a képzelet efféle ihletét, ha finomabb folyamatokat feltáró munkájával vetette egybe, az olyannal, amiben górcső nem segít, csupán belső fényük vezet a külvilág keserves útvesztőin át, mert szövétneke az energia tovább alig bontható elemi oka, mely akár a légi semmi porszemeit is világosságba foglalja. Lydgate maga elutasította a gyenge lelkek minden olcsó segédeszközét, és egyedül a belső fény szövétneke után haladt, amely a kutatás szeme egyszersmind: befogja a tárgyát, és a lélek következetességébe vonja részleteit. Azon finom folyamatok sötétjébe kívánt bele- 
exactness of relation; he wanted to pierce the obscurity of those minute processes which prepare human misery and joy, ... (194). világítani, amelyek az emberi szomorúság és öröm okozati láncát teszik, ... (I/201).

The relationship of the two texts is too rich to mention all its aspects. To begin with, 'invention' becomes 'segédeszköz.' This is one of those examples when the theoretical aspects of the original is turned into something more concrete. Besides, the Hungarian version uses the type of strange and rare words, 'górcső' and 'szövétnek,' which are sometimes considered to have some kind of poetic quality in themselves. Both are less straightforward than 'lens' and 'light' of the original. The phrase "légi semmi porszemei" also seems to be more artistic and much less clear than "ethereal atoms." It creates, at least for the Hungarian reader, an allusion to Attila József, even though no such reference can be justified. But not even the allusion to the Hungarian poet can make the contradiction of "semmi porszemei" acceptable. The English passage describes the pains Lydgate has to take in order to pierce obscurity; the Hungarian version goes in the opposite direction. It uses uncommon and obscure words, and thus raises both explicit and implicit, but in any case, premature doubts whether Lydgate will ever reach his goal. How many readers know, without looking it up in a dictionary, what 'szövétnek' is? Again, where the English text speaks of "long pathways of necessary sequence," the Hungarian version refers to the "külvilág keserves útvesztői."

Another characteristic of the Hungarian version is exaggeration. In the following example 'drab' becomes "örömtelen tehén."

Old provincial society had its share of this subtle movement: had not only its striking downfalls, its brilliant young professional dandies who ended by living up an entry with a drab and six children for their establishment, but also those less marked vicissitudes which are constantly shifting the boundaries of social intercourse, and begetting new consciousness of interdependence (122).

\begin{abstract}
A régi vidéki társadalom is széles országútja volt ezeknek a finom mozgásoknak, nem útvesztője csupán azon bámulatos tehetségü fiatal arszlánoknak, akik végül egy örömtelen tehénnel és hat gyermekkel együtt gyepesedtek be, hanem terelte a kevésbé ismert sorsokat is, a társadalmi szövevény új mintáit tervezte ily módon (I/116).
\end{abstract}

The passage shows some of the characteristics mentioned above: 'arszlán' is an archaic, uncommon word. And why is a considerable part of the last clause missing? Which English expression is the counterpart of "társadalmi szövevény"? "Social intercourse" or "consciousness of interdependence"? Are they too abstract? What can explain the appearance of 'minta' and 'tervez'? The answers to these 
questions cannot be found in the original. The emergence of these words can only be explained in terms of the context the translation creates.

There is also a degree of exaggeration involved when "great resolve" (p. 25.) becomes "szent elhatározás" (I/5). The word 'szent' is not entirely bad in the context of the opening passage of the novel. However, the expression "szent elhatározás" recalls, almost automatically, Endre Ady, and creates misleading intertextual connections and connotations.

Similarly, "züllöttek bele az átlagba" is much stronger than "to be shapen by the average." It is also very unclear why the expression "the story ... is hardly ever told even in their consciousness" is translated as "elmondani alig tudnánk."

The story of their coming to be shapen after the average and fit to be packed by the gross, is hardly ever told even in their consciousness; ... (174).
Elmondani aligha tudnánk, hogy züllöttek bele az átlagba, s hogyan lett belőlük tizenkettő egy tucatban, ... (I/177)

The most common characteristic of the relationship of the English and the Hungarian versions seems to be harmless enough at first sight. In these instances, an English expression is not translated by the expression that might be expected but by another expression that is quite appropriate in the given context. However, as the following three examples show, this operation upsets the metaphorical structures of the original. The words 'thread' and 'current' are parts of the first group of metaphors. 'Current' occurs eighthteen times in the novel. Only twice is it translated by 'áramlat' or 'áram.' This is, actually, the type of operation that demolishes the metaphorical structure of the original.

he felt no agitation, and had no sense that any new current had set into his life (193).

For the first time Lydgate was feeling the hampering threadlike pressure of small social conditions, and their frustrating complexity (210).

But in Dorothea's mind there was a current into which all thought and feeling were apt sooner or later to flow the reaching forward of the whole consciousness towards the fullest truth, the least partial good (235).
Izgalmat nem érzett, az a sejtelem sem környékezte, új kor nyílt életében (I/200).

Lydgate most érezte magát először a vidéki társadalom szorításában, apró bonyodalmainak útvesztőjében (I/219).

Dorothea lelkében azonban forrás buzgott, melynek vizébe beletorkollt minden gondolat, minden érzés előbbutóbb - s ez a teljes igazság a lehetséges legfőbb jó felé áramlott ( I/246).

The last example correlates 'current' and 'forrás.' In other contexts, this may be perfect. Here, however, it is rather unfortunate. We have a 'forrás' into which 
"minden gondolat, minden érzés" 'beletorkollt.' Needless to say, 'forrás' and 'torkolat' are hard to reconcile.

Finally, it should be mentioned that every Hungarian schoolgirl and schoolboy is taught that the repetition of words is one of the seven stylistic deadly sins. This is probably the reason why repetition is avoided - even in translation when the repetition is not the translator's but the author's responsibility. Is the translator entitled to 'correct' a stylistically underdeveloped author like George Eliot?

Let us suppose that somebody translates J. Hillis Miller's essays into Hungarian. Can he or she quote the published translation of the novel? Miller used more than seventy examples. With the possible exception of, perhaps, five of them, all his examples would have to be retranslated.

Translation criticism is a non-existent genre in Hungarian journals. Hungarian translators are not accustomed to the public criticism of what they produce. And it is quite easy to understand the reasons. It takes some time and effort to compare the English and Hungarian texts of a 900-page novel (the same argument applies to shorter books and non-fiction as well) - and why would you do that if what you find will never be published? As a consequence, the level of linguistic awareness is not very high. The situation may or may not change in the future, but until it does, nobody can complain that the world does not understand Hungarian literature.

\section{Notes}

1. J. Hillis Miller, "Narrative and History" ELH 41 (1974) 455-473, and J. Hillis Miller, "Optic and Semiotic in Middlemarch" in Jerome H. Buckley (ed.), The Worlds of Victorian Fiction. Cambridge: Harvard University Press, 1975. 125-145, George Eliot, Middlemarch. Harmondsworth: Penguin, 1965, George Eliot, Middlemarch. Trans. Bartos Tibor. Budapest: Európa Könyvkiadó, 1976.

2. Miller mentions (“Optic...” 125) Thackeray’s Vanity Fair, Dickens' Bleak House, Little Dorrit, Our Mutual Friend, and Trollope's The Way We Live Now.

3. Miller "Optic..." 128.

4. "That the texture of Middlemarch society as a whole may be accurately represented in a metaphor of woven cloth is taken for granted throughout the novel." Miller "Optic..." 130.

5. Miller "Optic..." 128.

6. Miller "Optic..." 129.

7. "A pervasive figure for the human situation in Middlemarch is that of the seer who must try to identify clearly what is present before him. This metaphor contaminates the apparently clearcut objectivist implications of the metaphor of the flowing web." Miller "Optic..." 136.

8. 'The part is 'really like' the whole, and an investigation of a sample will lead to valid conclusions about the whole." Miller "Optic..." 129.

9. "Each of those nodes in the social web which is a separate human being is endowed with a power to see the whole. This power is defined throughout the novel as essentially distorting." Miller "Optic..." 137 
